PHILOLOGY

\title{
МЕТОНИМИЯ В ЯЗЫКЕ ПОЛИТИКА
}

Байкадамова М. С., к.ф.н., дочент АО «Финансовая академия», г. Нур-Султан, Казахстан Нуржанова 3. М., к.ф.н., дочент ЕНУ имени Л.Н. Гумилева, г. Нур-Султан, Казахстан

\section{DOI: https://doi.org/10.31435/rsglobal_conf/25032021/7467}

Abstract. This article examines the features of the methods of metonymy as a mechanism of allegorical thinking in the language of politics. The authors give examples of metonymic synergistic models in a political context: product color, political concept; metonymic compression; name - product, name political trend, political idea, political activity; synecdoche "part - whole", "whole - part". To carry out the linguistic analysis, material from newspapers, magazines, news sites and other sources was used. The authors come to the conclusion that cognitive metonymy in the process of implementing mental models performs, firstly, the function of concretizing abstract political ideas, social phenomena and clearly, vividly represents them, and secondly, reflects an assessment, acts as a means of political assessment and implements an axiological function, thirdly, it serves as a means of a language game, contributing to the emotionality and effectiveness of a political text.

Keywords: metonymy, metonymic model, language of politics, cognitive metonymy, political context.

Введение. В процессе глобализации и интеграции Республики Казахстан в мировое экономическое пространство объектом пристального внимания ученых становится политический дискурс. В языке политика метонимия используется как один из основных механизмов иносказательного мышления. Если иносказательность метафоры основана на отождествлении объектов, явлений, понятий по их сходству, то иносказательность метонимии реализуется на основе связи (сопричастности) вещей (объектов, явлений, понятий) [1]. Необходимо также отметить, что метонимия - механизм речи, состоящий в регулярном или окказиональном переносе имени одного класса объектов или единичного объекта на другой класс или отдельный предмет, ассоциируемый с данными по смежности, сопредельности, вовлеченности в одну ситуацию. В основе метонимии лежат те или иные синтагматические связи: смежность в пространстве, причинно-следственные связи и т.д.

Цель. Целью статьи является выявить и проанализировать различные приемы метонимии, метонимические, синергические модели в языке политика.

Методы исследования. Метонимия - механизм вторичной номинации. Л.К. Жаналина отмечает, что «под вторичной номинацией понимается использование имеющихся в языке номинативных средств в новой для них функции наречения, вторичные номинации показывают возможность неоднократных контактов между внеязыковым рядом и звукорядом: мороженое (мясо) (прилагательн.) - мороженое (сущ.); заяи (животное) - заяи (трусливый человек) [2, с.65].

Метонимический механизм играет огромную роль в когнитивной деятельности человека, в том числе и в речемышлении, а также в порождении речи [3].

Метонимия представляет собой результат обозначения одной вещи через другую, ассоциирующейся с ней по смежности. Она основывается на взаимной связи или родстве понятий. При метонимии, а также при синекдохе когнитивная операция производится в пределах одной понятийной структуры, одного фрейма. В процессе метонимического сдвига суть когнитивной операции состоит в переносе наименования одного из составных элементов на другой. Метонимия также делает высказывание более лаконичным и одновременно - менее однозначным, и не дает никакого информационного приращения, никакого нового видения объекта речи, однако способствует лаконичной и прагматической характеристике предмета мысли.

В языке политика прием метонимии - один из способов синергетического обновления текста. Синергический характер метонимии проявляется в процессе столкновения значения слова, известного в языке, с зарождающимся политическим смыслом - результатом ментальной операции переноса по смежности, когда название одного предмета переносится на другой по смежности понятий. Языковая игра актуализируется в ходе диалектического процесса диссипации, когда в результате локализации действия в пределах политической метонимической модели происходят, с одной стороны, затушевывание неоднородного с 
политическим контекстом общеязыкового значения, с другой - зарождение новой неоднородности (новое значение), столкновение его со старым и актуализация его в ином окружении, его гомогенизация с политической средой и стабилизация в политическом наполнении. Наблюдаются противоречивые действия: 1) диссипация (рассеивание, погашение неоднородности старого значения в новой среде) и 2) бифуркация - зарождение нового, постепенно стабилизирующегося значения (политического) в новом смысловом наполнении актуальной неоднородности, приспосабливающейся к другому контексту, к системе. Это приводит к столкновению старого и нового смыслов, вытеснению первоначального значения на периферию и актуализации нового, соответствующего данной системе, что характеризует пополнение языка политики новыми образами, обогащающими арсенал политических средств.

В языке политика наблюдается использование следующих метонимических синергических моделей:

1) Признаковая модель «ивет - человек, люди». Данная модель реализуется в трех видах: а) ивет флага, под которым объединяются представители какого-либо политического течения - политические группировки, члены данной группы, поддерживающие ее установки, убеждения, ср.: «Для достижения реваншистских целей, возвращения потерянных в результате проведения конституциональной реформы властных полномочий президента, отстранения его «любых друзив» от власти политические оранжевые авантюристы...готовы сегодня на все, - заявил народный депутат Украины Владимир Матвеев (Экспресс К, 12.04.2007); «Украина готовится короновать «апельсинового» президента» (Комсомольская правда, Казахстан, 12.01.2005).

При метонимии прилагательных два предмета, явления, понятия объединяются на основе общего признака. В данном случае денотатом прилагательных являются качества, свойства, признаки предметов. Однако качество, свойство не существует без его носителя, и на значение прилагательного всегда проецируются значения носителя признака» [4, с. 123].

2) Цвет - обозначение течения, движения, действия приверженцев определенного политического течения, результат действий, например: «зеленая револючиия, "оранжевая революичя», «тюльпановая революиия», ср.: «Бывиий спикер Омурбек Текебаев предложил снова отложить этот проект. Ведь со дня «тюльпановой революиии» прошло еще слишком мало времени, и только сама история все правильно расставит по местам» (Экспресс К, 06.04.2006); «Результаты усердной работы западных эмиссаров на постсоветском пространстве с нескрываемым содроганием наблюдал весь мир: оранжевый переворот на Украине, революиия роз в Грузии, тюльпановый беспредел в Кыргызстане» (Экспресс, № 86, 16.05.2006); «Митинг против отмены льгот, прошедший в минувшую субботу в Уфе, неожиданно получил оранжевый оттенок среди уже привычных глазу синей символики ЛДПР, и красной КПРФ, и партии «Родина». На митинге вдруг появились оранжевые знамена и транспаранты. Просто скопировав цветовую символику, они добились нужного эффекта: центральная площадь Уфы в считанные минуты стала напоминать предновогодний бушующий Киев» (Комсомольская правда, Казахстан, № 2, 25.01.2005); «Так называемые «цветные» революции принесли народам молодых независимых государств не установление народовластия и благоденствия, а падение жизненного уровня» (Казахстанская правда, 14.08.2007); «Кстати, понимание демократии национальнодемократическим институтом США весьма своеобразно. Его можно наглядно проследить по хронологии «иветочно-горшочных револющий» в странах СНГ» (Экспресс К, № 86, 16.05.2006); «Затем грянула «розовая революция» в Грузии, приведшая к власти эмоционального М. Саакашвили» (К. Токаев. Свет и тень, с. 294); «В дальнейшем на базе «Инициативы» образовались новые объединения - «Зеленое спасение» и «Зеленый фронт», а многие активисты пошли дальше - начали создавать демократическую партию Казахстана» (Е. Ертысбаев. Казахстан и Назарбаев: логика перемен, с. 199). В данном примере «Зеленое спасение» и «Зеленый фронт» - это названия общественно-политического экологического движения.

3) Цвет: 1) выражение политической субъективной оценки, сравните случаи, когда наименование цвета, в частности «желтый» используется в политическом тексте для выражения негативной оценки, для обозначения бульварных изданий, бульварной информации, например: «Цвет «желтый» весьма часто используется в качестве оценочного средства для обозначения бульварных изданий (желтая газета), бульварной информации: «Нужна правда. Народ устал оттого, что ему врут. Желтая информащия не должна просачиваться на телевидение. Обязателен интерактив, предоставление зрителю возможности выразить себя, дать почувствовать, что он часть телевизионного мира. Тогда будет тандем и высокие рейтинги» (Инфо-Цес, 3.08.2007). 
4) Метонимическая модель «имя собственное» - политическое движение, лагерь, группа, политическая персона, выдвигающая определенные политические идеи, ср.: «Эту группу называли часто «днепропетровской дружиной», хотя в нее входило немало людей, никогда не работавших в Днепропетровске. Было бы правильнее называть ее командой Брежнева. При Брежневе его «команда» разрослась до слишком больших размеров» (Е. Ертысбаев. Казахстан и Назарбаев: логика перемен, с. 105); «Особенно активизировались летом 1990 года организации национально-демократического толка, такие, как «Желтоксан», «Жерұйық», «Ақиқат», «Азамат», «Форум», «Алтай», «Отечество», общество «Уральских казаков» (Е. Ертысбаев. Казахстан и Назарбаев: логика перемен, с. 213); «Компартия Казахстана дифференцировала перечисленные организации по их отношению к социализму: неприемлемость социализма для Казахстана провозгласили такие организации, как «Алаш», «Мемориал», представители Алма-Атинского филиала Демократического союза. Относительный нейтралитет проявляют «Бірлесу», «Зеленый фронт», «Қазақ тілі» и др. Провозглашают социализм ценою своих усилий, имея особую точку зрения на его сущность, партклубы: «Социал-демократическая партия Казахстана», движение «Азат», представители рабочего движения» (Е. Ертысбаев. Казахстан и Назарбаев: логика перемен, с. 213); «Состоялось даже несколько судебных разбирательств, и активисты «Азата» информировали общественность об истинных целях своего движения (проповедуя национальную идею суверенитета, лидеры движения, тем не менее, стремились избежать ярлыка «националистов») (Е. Ертысбаев. Казахстан и Назарбаев: логика перемен, с. 218).

Синекдоха. Она актуализируется в ходе реализации моделей «часть - целое», «целое часть», например, 1) часть (целое): «В свое время власть (часть целого - общество) вдалбливала в головы людей мысль о том, что Казахстан не готов к демократии, что вызвало ответный синдром политического абсентизма. Теперь с таким же рвением власть призывает людей прийти и проголосовать для того, чтобы реализовать свое «демократическое право» на выбор» (Казахстанская правда, 14.08.2007); «Если одна часть политической элиты не согласна с другой частью политической элиты, то это единственный способ для смены режима в России, - заметил он, - я пытаюсь этому способствовать». В своем заявлении Березовский обвинил правительство России в удушении демократии: «При нынешнем режиме не уважается свобода слова, пресса не свободна от политического контроля, политические оппоненты под угрозой, а выборы несвободные и нечестные», - подчеркнул олигарх (Экспресс, № 63, 12.07.2007); «Но режим был жестоким и сильным, а восточное смирение с обстоятельствами, своего рода мусульманский «кисмет» (предопределение), ощущение фатальной обреченности не одно столетие присутствовали в поведении и сознании казахов: «На все воля Аллаха» (Е. Ертысбаев. Казахстан и Назарбаев: логика перемен, с. 23); «Партийная власть в Казахстане к началу перестройки являлась традиционной основой жизнедеятельности республики» (Е. Ертысбаев. Казахстан и Назарбаев: логика перемен, с. 115); «И Абиш смирился, став при этом не просто лояльным режиму, а одним из тех ударных винтиков системы, без которых невозможны были знаменитые сталинские стройки» (Е. Ертысбаев. Казахстан и Назарбаев: логика перемен, с. 23); «Люди разных национальностей жили бедно, но дружно, помогая и поддерживая друг друга. Верхам не нужно было призывать людей к тому, чтобы крепить и сохранять единство, оно было естественным состоянием народа» (Е. Ертысбаев. Казахстан и Назарбаев: логика перемен, с. 25).

2) «часть - иелое», когда целое называется по цвету детали одежды, вещи. Так, метонимия «синие воротнички», «белые воротники», «серые воротнички» используется для обозначения различных категорий лиц, представителей электората, сравните определение: «Воротнички белье, cерые, синие - термины, используемые буржуазной политической экономией и социологией для обозначения различных категорий лиц наемного труда. Белье воротнички - инженернотехнический персонал и служащие; серые - работники отраслей социальной инфраструктуры, синие - рабочие, занятые физическим трудом» [63, 64]. Например: «А Клинтон выделяет свои победы в штатах с наиболее обширным электоратом. Например, Огайо и Калифорния. Кроме того, ее поддерживают женщины, производственные рабочие («синие воротнички»), а также испаноязычные американцы» (Экспресс К, № 46, 13.03.2008); «Обама утверждает, что победа Клинтона в таких крупных штатах, как Огайо, Аризона и Невада, не составляет для него конкуренции. Но в то же время он не убедил, что сможет заручиться поддержкой таких ключевых групп, как женщины, производственные рабочие («синие воротнички»), а также испаноязычные американцы, как это сделала Хиллари» (Экспресс К, №46, 13.03.2008). 
3) модель «целое - часть». Эта модель развертывается в плане «вместилище вместимость», когда целое «вместилище» предстает как целое, а содержание ее - вместимое обозначает то, что входит в целое, сравните, например, случаи, когда понятия «Белый дом», «Федеративный дом», «Ак Орда», «народ», «Партия» выступают в качестве целого понятия, совокупности людей или для обозначения правительства, власти: «Бельй дом. В Кратком словаре языка политика представлена следующая словарная статья: «Бельій дом - резиденция президента США в Вашингтоне. В переносном смысле под Бельм домом подразумевается правительство $C W A »[65,35]$; «А по информации, распространенной «Ак Ордой», президент во время этой же поездки в Талды-Курган, «выступая перед членами партии «Нур Отан» и жителями города, подчеркнул роль партии «Нур Отан» в успешной реализации социально-экономических и политических реформ и отметил опыт работы партии по привлечению в свои ряды молодежи и выдвижению активистов» (Казахстанская правда, 14.03.2007); «На второй сессии Верховного Совета Назарбаев убедительно, на конкретных примерах с цифрами обозначил свою позицию: «Ломать не трудно, построить сложнее. Можем ли мы вот так, легко и просто разрушить наш федеративный дом?» (Е. Ертысбаев. Казахстан и Назарбаев: логика перемен, с. 152); «Народ это добрая украинская женщина, мать Николая Литошко, полюбившая Нурсултана как родного сына. Народ - это жители Чемалгана, рабочие и мастера Темиртау и Днепродзержинска. А кто принял решение о направлении ста казахских юношей на учебу? Партия. Для Нурсултана все было предельно ясно и никаких абстрактных понятий о «народе» или «партии» он не видел» (Е. Ертысбаев. Казахстан и Назарбаев: логика перемен, с. 43).

Результаты исследования. Язык политика как индивидуально-дискурсивная подсистема языковой деятельности характеризуется в работе не только в плане использования человеком средств языка в качестве орудия общения, но и с точки зрения изучения вопросов о том, как в языковых единицах отразился сам человек, какие экспрессивные и выразительные средства он использовал для репрезентации политической картины мира, какую роль сыграла языковая личность политика в обеспечении развития своего языка как самоорганизующейся системы, как она способствовала выявлению когнитивно-синергетической сущности языка.

Метонимическими моделями в политическом контексте являются: 1) цвет изделия, какоелибо политическое понятие; 2) метонимическая компрессия; 3) имя - изделие, имя - политическое течение, политическая идея, политическая деятельность; 4) синекдоха «часть - целое», «целое часть». Синергия весьма активно проявляется в рамках фразеологической системы, которая представляет собой самоорганизующуюся систему, так как, во-первых, в данной системе наблюдается актуализация принципов коэволюционности и когерентности - факторов, создающих неоднородность в сплошной среде. Это факторы воздействия нелинейных обратных связей в сложной системе, рассматриваемые как диссипация. Неоднородность во фразеологической системе создается за счет привлечения в нее фразеологизмов, фразеологических калек из самых разных источников: калек из английского, с французского, греческого, латинского, тюркского и др. языков.

Выводы. Таким образом, мы видим, что когнитивная метонимия в процессе реализации ментальных моделей выполняет, во-первых, функцию конкретизации абстрактных политических идей, социальных феноменов и наглядно, рельефно представляет их, во-вторых, отражает оценку, выступает средством политической оценки и реализует аксиологическую функцию, в-третьих, служит средством языковой игры, способствующим эмоциональности, эффективности политического текста, новой ее самоорганизации на основе противоречивых факторов диссипации и бифуркации.

\section{ЛИТЕРАТУРА}

1. Бирих А.К. Метонимия прилагательных в современном русском языке // Вестник ЛГУ, Сер.2, 1987. Вып.1(2). - С.78-84.

2. Жаналина Л.К. Номинация и словообразовательные отношения: спецкурс / Министерство образования Республики Казахстан; Алматинский государственный университет им. Абая. Алматы, 1993. - 180 с., ноябрь 2004) - Екатеринбург: УГТУ - УПИ, 2005. - С. 173 - 176.

3. Кобозева И.М. МЫСЛЬ и ИДЕЯ на фоне категоризации ментальных имен // Логический анализ языка. Ментальные действия: [Сб. Ст.]. - М.: Прогресс, 1985. - 455 с.

4. Якобсон Р.О. Избранные работы. - М.: Прогресс, 1985. - 454 с. 